\title{
EFFECT OF FUNGICIDES ON FOLIAR BLIGHT OF BELL PEPPER (Capsicum annuum L.) IN MORANG, NEPAL
}

\author{
"Sanjib Chaudhary, Madan Ghimire, Nirmal Adhikari, \\ Ashok Sah, Santosh Kumar Yadav, Prabhat Swar \\ Purbanchal University - G. P. Koirala College of Agriculture and Research Center \\ (PU-GPCAR), Gothgaun, Morang, Nepal. \\ ${ }^{*}$ Corresponding Author \\ DOI: https://doi.org/10.51193/IJAER.2021.7407
}

\begin{abstract}
An experiment was conducted to manage foliar blight (Phytophthora spp.) of bell pepper in the research field of GPCAR from February to August 2020 in a randomized completely blocked design with three replications and seven treatments including control. The treatments consist of foliar spray of Moximate 72\% WP (Cymoxanil 8\% + Mancozeb 64\%), Amistar top 29.6\% SL (Azoxystrobin a.i. 18.2\% + Difenoconazole a.i. 11.4\%), Tebuconazole 25\% WG, Ridomil Gold (Metalaxyl 4\% + Mancozeb 64\%), Difenoconazole 25\% EC, SAAF (Carbendazim 12\% + Mancozeb 63\%) and Control. The treatments were applied after the initial symptoms appeared and disease parameters were recorded at 60, 75, and 90 days after transplantation and fruits were harvested at weekly intervals. Moximate were recorded as least diseases severity with high fruit yield as compared to the control and Tebuconazole and Amistar top showed satisfactory result whereas Ridomil gold and SAAF did not perform well. Therefore, Moximate is the bestrecommended fungicide while Tebuconazole and Amistar top could be the best alternative for the management of foliar blight of bell pepper.
\end{abstract}

Keywords: Phytophthora spp., Severity, Satisfactory, Fungicide.

\section{INTRODUCTION}

Foliar blight caused by Phytophthora capsici is one of the major problems of bell pepper in the Morang district, especially in open fields. The total cultivated area covered about 25 ha with 82 Mt production and 3.28 Mt/ha yield (MoAD, 2018/2019). The climatic condition of the Morang district is somewhat varied due to the elevation range from 60 masl to 2410 masl. It has a suitable environment in the hilly areas for bell pepper production, however, it is infected by a various number of diseases, among them, and the foliar blight disease has gained major 
importance in bell pepper cultivated in the open fields mainly during the rainy season. Foliar blight is one of the most widely distributed diseases causing yield loss from 43-100 percent (Liang et al., 1992). The pathogen infects all the parts of a plant, including leaves, stem \& shoots, branches, and fruits and survives in infected plant debris in the soil as mycelium and spore form. It spreads in two ways, i.e. over short distances through water and contaminated farm equipment and over long distances primarily in infected transplants or in the soil carried with pathogens (Agrios, 1988). The symptoms may appear on the foliar part of the host plant such as leaf blight, stem \& shoot blight, and fruit rot which causes defoliation in the host plant. The initial symptoms appear as water-soaked to dull or faded green leaf tissue area rapidly enlarges covering the entire leaf under humid conditions, resulting in premature leaf fall. Symptoms appear as dark-green water-soaked spots in contrast to the light green colour of the healthiest fruit tissue and these spots enlarge rapidly covering the entire fruit causing rotting of fruit (Gupta et al., 2018). Management of foliar blight is very difficult due to its catastrophic nature, complex soil ecosystem and also its unpredictability. So integrated management strategy is necessary to control soil-borne disease, which may include the use of chemicals, exploitation of biological agents and botanicals as disease management tools.

\section{MATERIALS AND METHODS}

The experiment was conducted from February to August 2020 in a Randomized Complete Block Design (RCBD) layout of seven treatments and three replications with an individual plot size of $6.25 \mathrm{~m}^{2}$. The soil condition of the research field was sandy loam, slightly acidic with medium organic matter, medium nitrogen, low phosphorus and low potash content. The recommended dose of farmyard manure (FYM) and fertilizers was applied during land preparation and other management practices were followed as per recommendation. The 'Indra' variety of bell pepper seedlings was transplanted to the research field on $11^{\text {th }}$ April, maintaining the spacing of $45 \mathrm{~cm}$ plants to plant and $45 \mathrm{~cm}$ row to row apart.

Table 1: Treatments used in field experiments

\begin{tabular}{clcc}
\hline S.N. & Treatments & Symbol & Recommended Dose \\
\hline 1 & $\begin{array}{l}\text { Moximate 72\% WP (Cymoxanil 8\%+ } \\
\text { Mancozeb 64\%) }\end{array}$ & T1 & 2 gm/litre water \\
2 & $\begin{array}{l}\text { Amistar Top (Azoxystrobin a.i. 18.2\%+ } \\
\text { Difenoconazole a.i. 11.4\%) }\end{array}$ & T2 & 1 ml/litre water \\
3 & Tebuconazole 25\% WG & T3 & 0.25 gm/litre water
\end{tabular}




\begin{tabular}{|c|c|c|c|}
\hline 4 & $\begin{array}{l}\text { Ridomil Gold 68\% WP(Metalaxyl 4\%+ } \\
\text { Mancozeb 64\%) }\end{array}$ & $\mathrm{T} 4$ & $2 \mathrm{gm} /$ litre water \\
\hline 5 & Difenoconazole $25 \%$ EC & T5 & $0.5 \mathrm{ml} /$ litre water \\
\hline 6 & $\begin{array}{l}\text { SAAF 75\% WP(Carbendazim 12\% + } \\
\text { Mancozeb 63\%) }\end{array}$ & T6 & $1 \mathrm{gm} /$ litre water \\
\hline 7 & Control & $\mathrm{T} 7$ & ----------- \\
\hline
\end{tabular}

After the initial symptoms appeared, the treatments (i.e. fungicides) was applied as a foliar spray in different days intervals, such as Moximate, Amistar top \& Ridomil gold was applied in 10 days interval of $1^{\text {st }}$ spray and Tebuconazole, Difenoconazole and SAAF was applied in 15 days interval of $1^{\text {st }}$ spray. The spray number varied from 3-4 and irrigation as per the need and also followed by the intercultural operation in 20-30 days interval after transplant.Disease parameters such as disease severity were recorded in 60,75 and 90 days after transplant (DAT), the number of infected and non-infected fruits and their weights were also recorded weekly. The disease scoring was recorded for foliar blight with the appearance of disease symptoms on the canopy of the plant either leaf blight, stem and shoot blight and fruit rot with the help of disease scale index (0-5) which was given by Monroy-Barbosa \& Bosland (2010). The recorded data were subjected to the ANOVA with the help of Rstudio application (R Development Core Team, 2008) and mean comparison among significant variables was done by LSD test at the $5 \%$ level of significance.

Table 2: Disease scoring scale index for Phytophthora Blight of Bell Pepper

\begin{tabular}{cl}
$\begin{array}{c}\text { Severity } \\
\text { Scale }\end{array}$ & \multicolumn{1}{c}{ Symptoms } \\
\hline 0 & No symptoms \\
1 & $\begin{array}{l}\text { Small lesion under the paper disc area (small, dry spot, with defined borders; } \\
\text { lesion associated with hypersensitive response), the paper disc was removed } \\
\text { from the original place to uncover lesion, discolouration in this leaf is } \\
\text { produced by the paper disc. }\end{array}$ \\
2 & $\begin{array}{l}\text { The dark green, water-soaked lesion is bigger than the paper disc area, } \\
\text { surrounded by pale yellow undefined borders (the paper disc was moved from } \\
\text { its original place to show lesion borders). }\end{array}$
\end{tabular}


$315 \%$ to $49 \%$ of leaf area is wilted (scalded) or necrotic).

$450 \%$ or more of the leaf is wilted.

$5 \quad 100 \%$ of the leaf is necrotic or the leaf has dropped off from the plant.

\section{RESULTS}

\subsection{Isolation}

Various scientists were proven that the isolates from diseased plant parts of the foliar blight of bell pepper were identified as Phytophthora capsici. Verma (1997) studied the pathogenicity test on bell pepper variety California Wonder and observed the characteristic disease symptoms on leaves and fruit after 30 and $32 \mathrm{~h}$ of inoculation with the sporangial suspension of Phytophthora capsici. Likewise, other more workers were also proved the pathogenicity of Phytophthora capsici at different development stages of the host plant resulting in foliar blight, seedling death, root rot, stem blight and fruit rot (Babadoost and Islam, 2003; Hausbeck and Lamour, 2004). The variability on isolates of $P$. capsici can be observed from one location to another, among different plants in the same location and different organs on the same plants (da Costa Ribeiro and Bosland, 2012). The pathogen P. capsici also infect the cucumbers and squash that causes lesions on fruits that are typically covered with white sporangia and cause fruit rot or stem rot (Ristaino \& Johnston, 1999).

\subsection{Disease Severity}

There was a highly significant difference $(\mathrm{p} \leq 0.001)$ among the treatments in disease severity at all three observations. Disease severity was recorded highest in control at all three dates of observation. At $60 \mathrm{DAT}$, the disease was not observed in Moximate $(0.00 \pm 0.00)$ treated plot, lowest disease severity was observed in Tebuconazole treated plots $(1.33 \pm 0.58)$, followed by Amistar Top (2.67 \pm 1.15$)$. At 75 DAT, the least disease severity was in Moximate $(1.33 \pm 0.58)$ treated plot, followed by Tebuconazole $(2.67 \pm 2.31)$, Amistar Top $(6.67 \pm 1.15)$ and Difenoconazole $(9.33 \pm 1.15)$. And from final observation (90 DAT), the lowest disease severity was recorded in Moximate $(6.67 \pm 1.15)$, followed by Tebuconazole (18.67 \pm 2.31$)$, Difenoconazole $(24.00 \pm 0.00)$ and Amistar Top $(25.33 \pm 3.06)$ treated plots. Among them, the effect of Moximate was best in all three observations, but a little fluctuation was seen between Amistar Top and Difenoconazole in comparison with two observations i.e. 75 DAT and 90 DAT. The least mean disease severity was recorded in Moximate (2.67 \pm 0.33$)$ and followed by Tebuconazole (7.56 \pm 0.69$)$ and Amistar Top (11.56 \pm 1.67$)$. 
International Journal of Agriculture and Environmental Research

ISSN: 2455-6939

Volume: 07, Issue: 04 "July-August 2021"

Table 3: Effect of different fungicides on the foliar blight of bell pepper at three observation dates in research field at GPCAR, Gothgaun, Morang during 2020.

\section{Treatments}

\section{Foliar Blight Severity (\%)}

\begin{tabular}{cllll}
\cline { 2 - 5 } & \multicolumn{1}{c}{$(\mathbf{6 0}$ DAT) } & \multicolumn{1}{c}{ (75 DAT) } & (90 DAT) & Mean FBS \\
\hline 1. Moximate & $0.00^{\mathrm{e}} \pm 0.00$ & $1.33^{\mathrm{d}} \pm 0.58$ & $6.67^{\mathrm{f}} \pm 1.15$ & $2.67^{\mathrm{f}} \pm 0.33$ \\
2. Tebuconazole & $1.33^{\mathrm{de} \pm 0.58}$ & $2.67^{\mathrm{d}} \pm 2.31$ & $18.67^{\mathrm{e}} \pm 2.31$ & $7.56^{\mathrm{e}} \pm 0.69$ \\
3. Amistar Top & $2.67^{\mathrm{d}} \pm 1.15$ & $6.67^{\mathrm{c}} \pm 1.15$ & $25.33^{\mathrm{d}} \pm 3.06$ & $11.56^{\mathrm{d}} \pm 1.67$ \\
4. Difenoconazole & $5.33^{\mathrm{c}} \pm 1.53$ & $9.33^{\mathrm{bc}} \pm 1.15$ & $24.00^{\mathrm{d}} \pm 0.00$ & $12.89^{\mathrm{d}} \pm 0.19$ \\
5. Ridomil Gold & $6.67^{\mathrm{bc} \pm 1.15}$ & $10.67^{\mathrm{b}} \pm 1.15$ & $32.00^{\mathrm{c}} \pm 2.00$ & $16.44^{\mathrm{c}} \pm 1.02$ \\
6. SAAF & $8.00^{\mathrm{b}} \pm 1.00$ & $12.00^{\mathrm{b}} \pm 2.00$ & $40.00^{\mathrm{b}} \pm 5.29$ & $20.00^{\mathrm{b}} \pm 1.67$ \\
7. Control & $12.00^{\mathrm{a}} \pm 1.00$ & $18.67^{\mathrm{a}} \pm 2.31$ & $50.67^{\mathrm{a}} \pm 3.06$ & $27.11^{\mathrm{a}} \pm 1.84$ \\
\hline Mean & 5.14 & 8.76 & 28.19 & 14.03 \\
\hline LSD 0.05 & 1.79 & 2.73 & 4.88 & 2.10 \\
CV(\%) & 19.52 & 17.49 & 9.73 & 8.39 \\
F-Test & $* * *$ & $* * *$ & $* * *$ & $* * *$
\end{tabular}

PROC: Percentage Reduction Over Control; LSD: Least Significant Difference; CV: Coefficient of Variation; *: Significant at 0.05 level of significance; **: Significant at 0.01 level of significance; ***: Significant at 0.001 level pf significance; Values with same letters in a column are not significantly different at $5 \%$ level of significance by LSD test and figures after \pm indicate standard error values.

\subsection{Yield}

The number of non-infected fruit, infected fruit and yield per plant were highly significant different $(\mathrm{p} \leq 0.001)$ among the treatments. Moximate $(5.44 \pm 0.19)$ was the highest number of noninfected fruit producers, followed by Tebuconazole (4.33 \pm 0.67$)$, Difenoconazole $(4.00 \pm 0.58)$ and Amistar Top (3.56 \pm 0.96$)$. The least number of infected fruit was carried out by the Moximate $(0.00 \pm 0.00)$ treated plot, followed by Tebuconazole $(0.11 \pm 0.19)$, Difenoconazole (0.44 \pm 0.09$)$, Amistar Top (0.44 \pm 0.38$)$ and SAAF (0.56 \pm 0.09$)$. The highest plant yield (gm/plant) was recorded in Moximate (520.50 \pm 24.41$)$ treated plot, followed by Tebuconazole (418.30 \pm 7.61$)$ and Difenoconazole (394.63 \pm 8.14$)$ and the least yield was recorded in the Control (148.33 \pm 8.94$)$ plot. 
Table 4: Effect of treatments over foliar blight disease concerning yield of bell pepper in research field at GPCAR, Gothgaun, Morang during 2020.

\begin{tabular}{llcc}
\hline \multirow{2}{*}{ Treatments } & \multicolumn{2}{c}{ Number of fruits } & \multirow{2}{*}{ Yield (gm/plant) } \\
\cline { 2 - 4 } & Non-Infected & Infected & \\
\hline 1. Moximate & $5.44^{\mathrm{a}} \pm 0.19$ & $0.00^{\mathrm{e}} \pm 0.00$ & $520.50^{\mathrm{a}} \pm 24.41$ \\
2. Tebuconazole & $4.33^{\mathrm{ab}} \pm 0.67$ & $0.11^{\mathrm{de}} \pm 0.19$ & $418.30^{\mathrm{b}} \pm 7.61$ \\
3. Difenoconazole & $4.00^{\mathrm{b} \pm 0.58}$ & $0.44^{\mathrm{cd}} \pm 0.09$ & $394.63^{\mathrm{b}} \pm 8.14$ \\
4. Amistar Top & $3.56^{\mathrm{bc} \pm 0.96}$ & $0.44^{\mathrm{cd}} \pm 0.38$ & $300.83^{\mathrm{c}} \pm 10.90$ \\
5. SAAF & $2.56^{\mathrm{cd} \pm 0.96}$ & $0.56^{\mathrm{c}} \pm 0.09$ & $227.68^{\mathrm{d}} \pm 15.46$ \\
6. Ridomil Gold & $2.11^{\mathrm{d}} \pm 0.38$ & $1.22^{\mathrm{b}} \pm 0.19$ & $207.59^{\mathrm{d}} \pm 23.76$ \\
7. Control & $1.44^{\mathrm{d}} \pm 0.77$ & $2.56^{\mathrm{a}} \pm 0.19$ & $148.33^{\mathrm{e}} \pm 8.94$ \\
\hline Mean & 3.35 & 0.76 & 316.84 \\
\hline LSD 0.05 & 1.14 & 0.33 & 29.66 \\
CV(\%) & 19.20 & 24.8 & 5.26 \\
F-Test & $* * *$ & $* * *$ & $* * *$
\end{tabular}

PIOC: Percentage Increase Over Control; LSD: Least Significant Difference; CV: Coefficient of Variation; *: Significant at 0.05 level of significance; ***: Significant at 0.001 level of significance; Values with same letters in a column are not significantly different at $5 \%$ level of significance by LSD test and figures after \pm indicate standard error values.

\section{DISCUSSION}

\subsection{Effect of fungicides on disease severity of foliar blight of bell pepper}

The study revealed the outstanding result in maximum disease reduction was brought by the Moximate, whereas, the Tebuconazole was also good enough to foliar blight and fair with Amistar Top and Difenoconazole whereas SAAF did not show better performance.

The result of this study was supported by findings that of Samoucha \& Cohen (1988), who proves that cymoxanil performs better than metalaxyl which means Moximate is the far better fungicide than Ridomil gold. Cymoxanil 8\% + Mancozeb 64\% has the highest protection (100\%) with maximum yield against Phytophthora spp. which causes late blight of potato under field condition (Sharma \& Saikia, 2013; Kumar et al., 2018). NA \& MS (2016), reported that 
International Journal of Agriculture and Environmental Research

ISSN: 2455-6939

Volume: 07, Issue: 04 "July-August 2021"

Cymoxanil 8\%+Mancozeb 64\%) with Hexaconazol 5\% was very effective for the control of foliar blight. Gupta and Jarial (2010), recorded that Cymoxanil + Mancozeb was exhibited 100 percent disease control against leaf blight and fruit rot of bell pepper. Mhatre et al. (2020), proved that mancozeb-cymoxanil + mancozeb and chlorothalonil-ametoctradin + dimethomorph were best fungicidal against late blight of potato with resulting highest yield parameters.

Furthermore, Tebuconazole shows the second-best performance after Moximate, which was also the better alternative for blight diseases and followed by Amistar Top and Difenoconazole. The available literature on different fungicides also revealed the efficacy of copper oxychloride, mancozeb, captafol, Ridomil-MZ and Sectin against the different Phytophthora spp. causing leaf blight and fruit rot of bell pepper plants (Chaudhary and Banyal, 2013). Tebuconazole has a good effect on foliar blight reduces maximum disease severity and its foliar application also gave the best result and reduced the late leaf spot intensity (Padmaja, 2013). Saha et al. (2018) reported that the combination of fungicides: trifloxystrobin $(25 \%)+$ tebuconazole $(50 \%)$ showed the best control against leaf spots in both in vitro and in vivo conditions. Amistar top has been proven to effective inhibitory for foliar blight where better results were performed (Sing, 2015; Rebollar-Alviter \& Ellis, 2005). Elansky et al. (2016), mentioned that the difenoconazole performance was a good inhibitor against late blight of tomato and potato under the laboratory test on Agar growth medium with detached leaf in Cercospora leaf spot in okra (Beura et al., 2013). The last performance was recorded by the SAAF in comparison with Moximate where various supports gave as Gupta \& Jarial (2010) revealed that the Carbendazim 12\% + Mancozeb $63 \%$ performed low disease control against foliar blight and fruit rot in bell pepper. Also recorded least disease control with the lowest yield and low cost-benefit ratio in the late blight of potato (Kumar et al., 2018; Khadka et al., 2020).

Ridomil gold cannot show good performance in the present research study against the foliar blight of bell pepper. However, it showed a good effect in other journals of researchers, i.e. (Babadoost et al., 2015; Matheron and Porchas, 2008). Also perform well on Cercospora leaf spot on chilli without showing any phytotoxicity symptoms (Kumar et al., 2016), late blight of potato (NA \& MS, 2016).

In addition, the agrometeorological data showed that there was heavy rainfall occurred from the $2^{\text {nd }}$ week of June to the $3^{\text {rd }}$ week of July with low temperature, which might be suitable for the growth of the Phytophthora pathogen and leads to increased disease severity and loss in yield. These were supported by Chaudhary and Banyal (2013) reported that the temperature and relative humidity are the most important environmental factors contributing to foliar blight disease development and presented 80 to 85 percent of disease severity in bell pepper. Similarly, Bhardwaj et al. (1985) also reported that the disease development was positively correlated with high relative humidity, rainfall and temperature. 
International Journal of Agriculture and Environmental Research

ISSN: 2455-6939

Volume: 07, Issue: 04 "July-August 2021"

\subsection{Effect of Fungicides on Yield of Phytophthora blight of Bell Pepper}

The enhancement in fruit yield of the bell pepper with foliar sprays of Moximate, Tebuconazole and Difenoconazole might be the reduction in disease due to which plants get less stress and become healthy and bearing healthy, quality and nutritious fruits with maximum size which leads to the increase in yield. There were no phytotoxicity observed in the application of such fungicides with the recommended dose and helps in the suppression of harmful fungal diseases like foliar blight, root rot, stem blight, fusarium wilt, fruit rot, Cercospora leaf spots, etc.

The literature relates to Beard et al. (2004), who was reported that the rate of disease progression was retarded with the application of fungicides. Cymoxanil + Mancozeb (i.e. Moximatte) has high disease control capacity with leading to the highest yield (Sharma \& Saikia, 2013). Nithya Meeakshi et al. (2006), reported the non-phytotoxic nature of Azoxystrobin and difenoconazole with the recommended dose at or below for field application.

\section{CONCLUSION}

Among all the treatments, Moximate 72\% WP (Cymoxanil 8\% + Mancozeb 64\%) performed best in the reduction of disease severity of foliar blight with a higher fruit yield of Bell Pepper whereas Tebuconazole 25\% WG, Amistar Top (Azoxystrobin a.i. 18.2\% + Difenoconazole a.i. $11.4 \%$ ) and Difenoconazole 25\% EC was also done well as satisfactory. Therefore, Moximate becomes the best fungicide for the control of the foliar blight disease of bell pepper. However, other works of literature reported that Ridomil Gold 78\% WP was performed well, but in my research, evaluation, Ridomil Gold 78\% WP (Metalaxyl 4\% + Mancozeb 64\%) and SAAF 75\% WP (Carbendazim 12\% + Mancozeb 63\%) had an at least performance with comparison to Moximate $72 \%$ WP. Therefore, Moximate (cymoxanil 8\% + Mancozeb 64\%) is the bestrecommended fungicide for the control of foliar blight of bell pepper and is worth it.

\section{ACKNOWLEDGEMENTS}

I would like to express my special thanks of gratitude and a sense of appreciation to Mr. Nirmal Adhikari, Assistant Lecturer at Purbanchal University - G. P. Koirala College of Agriculture and Research Centre (GPCAR) for his continuous guidance, supports, constant motivation, affection, encouragement and valuable suggestions during the entire period of research. I'm grateful to Mr. Shashan Devkota, Guest Lecturer of GPCAR and also my sincere thanks to my parents, colleagues, GPCAR Student Team and all helping hands for their valuable help and cooperation. 
International Journal of Agriculture and Environmental Research

ISSN: 2455-6939

Volume: 07, Issue: 04 "July-August 2021"

\section{REFERENCES}

Agrios G N. 1988. Plant pathology. 3rd edition Academic Press. New York, p803.

Babadoost M and Islam S Z. 2003. Fungicide seed treatment effects on seedling damping-off of pumpkin caused by Phytophthora capsici. Plant Dis. 87: 63-68.

Babadoost, M., Pavon, C., Islam, S. Z., \& Tian, D. (2015, December). Phytophthora blight (Phytophthora capsici) of pepper and its management. In XXIX International Horticultural Congress on Horticulture: Sustaining Lives, Livelihoods and Landscapes (IHC2014): International Symposia on Innovative Plant Protection in Horticulture, Biosecurity, Quarantine Pests, and Market Access (pp. 61-66). International Society for Horticultural Science.

Beard, C., Jayasena, K., Thomas, G., \& Loughman, R. (2004). Managing stem rust of wheat. Plant Pathology, Department of Agriculture, Western Australia, 8, 23-34.

Beura, R. C., Nayak, N., \& Beura, S. K. (2013). Economics and chemical management of Cercospora leaf spot of okra under Bhubaneswar condition. Journal of Plant Protection and Environment, 10(2), 61-64.

Bhardwaj, S. S., Sharma, S. L., \& Dohroo, N. P. (1985). Role of meteorological factors in development of bell pepper fruit rot (Phytophthora nicotianae var. nicotianae Waterhouse). J. Mycol. Pl. Pathol, 15, 328-329.

Chaudhary, J. A. Y. A., \& Banyal, D. K. (2013). Effect of environmental factors on Phytophthora nicotianae var. nicotianae and evaluation of bell pepper germplasm. Indian Phytopathol, 66(1), 41-45.

Chaudhary, J., \& Banyal, D. K. (2013). Status and distribution of Phytophthora leaf blight and fruit rot of capsicum in Himachal Pradesh and its management through fungicides. Indian Phytopathology, 66(2), 135-139.

da Costa Ribeiro, C. and Bosland, P., 2012. Physiological Race Characterization of Phytophthora capsici Isolates from Several Host Plant Species in Brazil Using New Mexico Recombinant Inbred Lines of Capsicum annum at Two Inoculum Levels. Journal of the American Society for Horticultural Science, 137(6), pp.421-426.

Elansky, S. N., Mita, E. D., Skolotneva, E. S., Pobedinskaya, M. A., \& Kokaeva, L. Y. (2016). Effect of difenoconazole on the formation of oospores by Phytophthora infestans(Mont) de Bary. Journal of Plant Pathology, 123-127. 
International Journal of Agriculture and Environmental Research

ISSN: 2455-6939

Volume: 07, Issue: 04 "July-August 2021"

Gupta, S. K., \& Jarial, K. (2010). Comparative efficacy of two strobilurins in management of leaf blight and fruit rot (Phytophthora nicotianae var. nicotianae) of bell pepper. Indian Phytopathology, 63(2), 216-218.

Gupta, S. K., \& Thind, T. S. (2018). Disease problems in vegetable production. Scientific publishers.

Hausbeck M K and Lamour K H. 2004. Phytophthora capsici on vegetable crops research progress and management challenges. Plant Dis. 88: 1292-1303.

Khadka, Ram Bahadur, et al. (2020). "Evaluation of Fungicides to Control Potato Late Blight (Phytophthora Infestans) in the Plains of Nepal." Journal of Phytopathology, vol. 168, no. 5, May 2020, pp. 245-53. DOI.org (Crossref), doi:10.1111/jph.12886.

Kumar, A. M., Kumar, R. U., \& Kumar, R. N. (2016). FIELD EVALUATION OF NEW FUNGICIDE MOLECULE (RIDOMIL TION OF NEW FUNGICIDE MOLECULE (RIDOMIL GOLD 68\% WP) AGAINST LEAF SPOT OF CHILLI.

Lee, S. O., \& Chung, B. K. (1989). Effect of new systemic fungicides metalaxyl-MZ and AlietteF for controlling red pepper fruit rot caused by Phytophthora capsici. The Korean Journal of Mycology, 17(4), 184-188.

Liang, Y., Lu, J. D., \& Ji, R. Z. (1992). Study on the occurrence and yield loss of pepper Phytophthora blight in Shaanxi. Plant Protection, 1, 14-15.

Mhatre, P., Lekshmanan, D., Palanisamy, V., Bairwa, A. and Sharma, S., 2020. Management of the late blight (Phytophthora infestans) disease of potato in the southern hills of India. Journal of Phytopathology, 169(1), pp.52-61.

MOAD (2018/2019). Statistical information on Nepalese Agriculture 2018/2019. Ministry of Agriculture Development. Government of Nepal. Kathmandu.

Monroy-Barbosa, A., \& Bosland, P. W. (2010). A rapid technique for multiple-race disease screening of Phytophthora foliar blight on single Capsicum annuum 1. Plants. HortScience, 45(10), 1563-1566. https://doi.org/10.21273/HORTSCI.45.10.1563

NA, S., \& MS, A. (2016). Comparative Efficacy of Different Fungicides against Late Blight Diseases of Potato incited by Phytophthora infestans (Mont.) de Bary and its Management. Journal Of Plant Pathology \& Microbiology, 7(7). doi: 10.4172/21577471.1000364 
Nithyameenakshi, S., Jeyaramraja, P. R., \& Manian, S. (2006). Investigations on phytotoxicity of two new fungicides, azoxystrobin and difenoconazole. American Journal of Plant Physiology, 1(1), 89-98.

Padmaja, G. (2013). STUDIES ON PHYTOPHTHORA LEAF BLIGHT OF TARO (Colocasia esculenta (L.) Schott.) (Doctoral dissertation, ACHARYA NG RANGA AGRICULTURAL UNIVERSITY).

R Development Core Team. 2008. R: A language and environment for statistical computing. R Foundation for Statistical Computing, Vienna, Austria. ISBN 3-900051-07-0.

Rebollar-Alviter, A., \& Ellis, M. A. (2005). Efficacy of azoxystrobin, pyraclostrobin, potassium phosphite, and mefenoxam for control of strawberry leather rot caused by Phytophthora cactorum. Plant Health Progress, 6(1), 17. https://doi.org/10.1094/PHP-2005-0107-01-RS

Ristaino, J. B., \& Johnston, S. A. (1999). Ecologically based approaches to management of phytophthora blight on bell pepper. Plant Disease, 83(12), 1080-1089. https://doi.org/10.1094/PDIS.1999.83.12.1080

Saha, S., Sandip Hingmire, T. P., Shabeer, A., Banerjee, K., Ashtekar, N., \& Patil, A. (2018). Assessment of Trifloxystrobin 25\%+ Tebuconazole 50\%-75 WG Bioefficacy, Safety and Residue Dynamics against Leaf Spot of Cabbage. Chemical Science Review and Letters, 7(28), 867-874.

Samoucha, Y., \& Cohen, Y. (1988). Synergistic interactions of cymoxanil mixtures in the control of metalaxyl-resistant Phytophthora infestans of potato. Phytopathology, 78(6), 636-640.

Sharma, P., \& Saikia, M. K. (2013). Management of late blight of potato through chemicals. IOSR J Agric Vet Sci, 2, 23-36.

Sing, A. K. (2015). EPIDEMIOLOGY AND MANAGEMENT OF PHYTOPHTHORA LEAF BLIGHT AND FRUIT ROT OF BELL PEPPER (Doctoral dissertation, Dr Yashwant Singh Parmar University of Horticulture and Forestry).

Verma S. 1997. Epidemiology and management of leaf blight and fruit rot of bell pepper. M. Sc. thesis, UHF, Solan. 82p 